\title{
THE ROLE OF RELIGIOUSITY MEDIATING ISLAMIC ATTRIBUTES ON TOURIST PREFERENCE AT SHARIA-COMPLIANCE HOTEL
}

\author{
Filda Rahmiati', Anita Rizki Fajarsari ${ }^{2}$ \\ ${ }^{1}$ Management Study Program, President University \\ Email: filda.rahmiati@gmail.com \\ ${ }^{2}$ Management Study Program, President University \\ Email: fajarsarianitarizki@gmail.com
}

\begin{abstract}
ABSTRAK
Meningkatnya populasi Muslim di seluruh dunia membuat meningkatnya permintaan Pariwisata Halal. Karena Indonesia adalah negara dengan populasi Muslim terbesar di dunia, diharapkan menduduki peringkat pertama para pariwisata halal termasuk hotel yang mematuhi hukum Syariah. Namun, Indonesia menempati posisi ke-2 pada Muslim-Friendly sementara Malaysia sebagai peringkat pertama negara Pariwisata Halal. Oleh karena itu, peneliti melakukan penelitian ini untuk mengetahui preferensi wisatawan terhadap hotel halal di Indonesia sebagai salah satu kriteria untuk membangun pariwisata halal. Penelitian ini menyelidiki pengaruh Islamic physical attributes (Atribut Fisik Islami), Islamic non-physical attributes (Atribut Non Fisik Islami) dan Religiosity (Keagamaan) sebagai moderator pada Tourist Preference (Preferensi Turis) of Shariah-compliance hotel (Hotel kepatuhan Syariah) di Indonesia. Penelitian ini menggunakan 100 responden hotel halal yang menggunakan non-probability sampling dengan teknik Convenience sampling dan menggunakan pendekatan penelitian positivis dengan metode kuantitatif dan survei melalui kuesioner. Untuk menganalisis data, Partial Least Square - Structural Equation Model (PLSSEM) dianalisis menggunakan SmartPLS 3.2.8. Hasil penelitian ini menunjukkan bahwa Islamic non-physical attributes berpengaruh signifikan terhadap Tourist Preference. Religiosity memiliki pengaruh moderat yang signifikan dari Islamic non-physical attributes pada Tourist Preference. Padahal, Islamic physical attributes tidak berpengaruh signifikan terhadap Tourist Preference. Dengan demikian, disarankan bagi hotel untuk menerapkan Islamic non-physical attributes seperti lantai terpisah, kolam renang, juga senam untuk pria dan wanita.
\end{abstract}

Kata Kunci: Atribut Fisik Islam, Atribut Non-fisik Islam, Keagamaan, Preferensi Turis, Hotel Kepatuhan Syariah.

\begin{abstract}
The rising of Muslim population around the world makes the increasing of demand of Halal Tourism. As Indonesia is a country with the largest population of Muslim around the world should become the leader of Halal tourism including Shari'ah compliance hotel. However, Indonesia positioned 2nd place of Muslim-Friendly destination while Malaysia as a leader of the Halal Tourism country. Therefore, the researcher conducted this research to find out the tourist preference toward halal hotel in Indonesia as one of the criteria to build halal tourism. This study investigates the influence of Islamic physical attributes, Islamic non-physical attributes and Religiosity as moderating on tourist preference of Shariah-compliance hotel in Indonesia. This research uses 100 respondents of Halal hotel which is using non-probability sampling with Convenience sampling technique and using a positivist research approach with a quantitative method and a survey through questionnaires. To analyze the data, Partial Least Square - Structural Equation Model (PLS-SEM) analyzed using SmartPLS 3.2.8. The result of this research indicated that Islamic Non-physical Attributes has significant influence on Tourist Preference. Religiousity has significant moderating influence of Islamic Non-physical Attributes on Tourist Preference. Whereas, Islamic Physical Attributes has not significantly influence on Tourist Preference. Thus, it is recommended for hotels to implement the Islamic Non-physical Attributes such as separate floors, swimming pool, also gymnastic for men and women.
\end{abstract}

Keywords: Islamic Physical Attributes, Islamic Non-physical Attributes, Religousity, Tourist Preference, Shariahcompliance Hotel.

\section{INTRODUCTION}

Research Background

Islamic principle of Shari'ah became trend of lifestyle in the whole sector, no exception in hospitality and tourism industry as an important in worldwide economy (Committee for 
Economic and Commercial Cooperation of the Organization of Islamic Cooperation, 2016; ElAdly \& Eid, 2017; Enda, 2015). Supported by the report from World Travel and Tourism Council (WTTC, 2017) tourism is one of the largest economics sectors in the world. Therefore, the development in the tourism industry is very rapid. Evidenced by the latest trends regarding Shari'ah can quickly be implemented in the tourism industry for example, the Shariah hotel.

Halal hotel or Sharia-Compliant Hotel become the new trend in most of Muslim scholars, especially in Asia. Based on Global Muslim Travel Index (GMTI) (2018) Indonesia become $2^{\text {nd }}$ place of Muslim country that become Muslim destination assessed with criterias of MuslimFriendly facilities and services after Malaysia. Added by the tagline "Wonderful Indonesia" in 2015 with sub theme "Wonderful Indonesia as a Muslim Friendly Destination" (Sofyan, 2015). Further, Indonesia has big opportunity especially in attracting domestic tourist as Indonesia is the largest country of Muslim population, more than $80 \%$ people of 265 million people in Indonesia are Muslim. In serving sharia hotels, of course, much must be prepared by Indonesia. This study adopted variables based on Battour \& Ismail (2011) three major factors that impact Muslim choice: Muslim tourist preference, Islamic tangible attributes and Islamic intangible attributes. Strengthened by Religiosity theory from Huber \& Huber (2012) as religiousity become one of the reasons for people to choose destination. Thus, this research aims to find out the islamic attributes (physical and non-physical) mediated by religiousity influence tourist preference toward halal hotel in Indonesia.

\section{Shariah-Compliance hotel}

Shariah-Compliance hotel also popular as Halal hotel attributes is the hotel that will not serving non-halal food and no alcohol at the restaurant or hotels (Zakiah \& Fadhil, 2013) mini bar is not allowed in hotels (Sahida et al, 2011). In addition, Quran and praying equipments should be available with the Qibla sign sticked in hotel room. The position of bed and toilet not facing the Qibla. The last important thing is the prayer room must be available in the buildings of the hotels (Idris \& Abdul, 2015). Shariah-Compliance hotel also creating regulation on the dress code. Based to Shariah regulation, Muslim woman must cover their hair and body as mentioned in Quran "Prophet, tell your wives and daughters and the believing women to draw their outer garments around them (when they go out or are among men) (Quran, 33:59). Thus, the staff must wear proper clothes. It also applied to the facilities such as salon, gymnastic and swimming pool that should be separated between men and woman. Moreover, for the room it should separate the floor based on the gender or family members (Idris \& Abdul, 2015).

Muslims considered halal (permitted) and haram (forbidden) as the term of what God defines as the good and bad choice of a person (Halstead, 2007) not only prefers to food and beverages (Mohsin et al, 2015) but also consider in the tourism industry such as hotel. Muslim also consider halal service based on Islamic value, it also has relevance with the rules of Shari'ah or religious identity (Eid \& El-Gohary, 2015). According to Putra et al (2016), the value consists two dimensions of islamic physical attributes and islamic non-physical attributes.

\section{Islamic Physical Attributes}

In Islam, Muslims are forbidden to do several things such as adultery, gambling, consumption of pork and other haram (forbidden) foods, selling or drinking liquor and dressing inappropriately (Eid \& El-Gohary, 2015). In the terms of tourism, Muslim also consider the Islamic Value in services based on Shari'ah Principles (Committee for Economic and Commercial Cooperation of The Organization of Islamic Cooperation, 2016; Eid \& El-Gohary, 2015; Chanin, 2015). Shari'ah principles refer to all that is commanded and something which is permissible called 
halal (Wingett \& Turnbull, 2016). Islamic Physical attributes are the attributes that can be seen and touch such as availability of worship tools, worship facilities, toilets that accordance with Islamic rules (Putra et al., 2016). It also served halal food and alcohol-free beverages (Battour \& Ismail, 2010).

\section{Islamic Non-Physical Attributes}

Beside Islamic physical attributes, there is also non-physical attributes that become one of the dimensions in Islamic Value (Eid \& El-Gohary, 2015; Putra et el., 2016). It shapes to all attributes that can be seen but not necessarily touched directly (Putra, 2016). There are examples of non-physical attributes of Islam such as appropriate entertainment (Putra et al., 2016), predominantly Muslim staff, conservative staff dress code, separated floor for men and woman that travel without family, separated swimming pool and gymnastic both men and woman (Henderson, 2010).

\section{Religiousity}

One of the major elements of development in human history and civilization are religion. Religious defines as the ideas for life that reflected the value or worth and the attitude in the societies and individuals (Zamani-Farahani \& Musa, 2012). The definition of Religiosity is characterized similarly as those level of obligation towards religious practice and standards (Islam \& Chandrasekaran, 2015). Religiosity also become the moderates of Islamic Physical Attributes and Islamic Non-Physical Attributes, it shows the importance of Islamic Attributes on Muslim consumer's willingness toward tourism product (Eid \& El-Gohary, 2015).

\section{RESEARCH METHODOLOGY}

In this research quantitative approach applied. Quantitative approach is the approach that is done by recording and analyzing the data of research results exactly by using statistical calculation. Quantitative research involves collect data then calculated to statistical treatment to support or reject the hypothesis (Creswell, 2014).

\section{Population and Sample}

This study applied a non-probability sampling with purposive sampling. Sugiyono (2017) said purposive sampling is techniques to determine the research sample using considerations, criteria, or characteristics to obtain data. The population in this research are the local tourist who are Muslim and have been stayed at hotel in Indonesia. According to Sarwono (2013) minimum number of samples 100 with an error rate of $10 \%$ to obtain significant and more accurate analysis results. Thus, this study will use 100 samples with significan level of $5 \%$.

\section{Data Collection Method}

This study using primary data that obtained directly from the questionnaire to collect data. The questionnaire created from previous studies. The questionnaire is divided into three sections where the first section is filtering question which this questionnaire intended for Muslims and who have stayed at hotels. Next, demographic profile and last is variables in this study of Islamic Physical Attributes, Islamic Non-physical Attributes mediated by Religiosity on Tourist Preference on staying at Sharia-Compliant Hotel in Indonesia. The total of the questions is consisting of 30 questions and the respondent were asked to answer the agreement level that related to the variables chosen by using five points Likert scale ranging from strongly disagree to strongly agree. 


\section{Data Analysis}

This study using SmartPLS 3.2.8. software to analyse the data. In general, covariance-based SEM is preferred when the research objective is confirmatory modeling (Garson, 2016). By using PLS-SEM an evaluation of the measurement model (outer model) analysis shows how the manifest variable represents the latent variable to be measured. In PLS-SEM to get a model that is fit or what can be called a pre-test, then this research tests the quality of the measurement model. To evaluate the goodness of fit of the outer measurement model, there are three requirements that must be considered, namely, convergent validity, discriminant validity, and reliability.

\section{Hypotheses Testing}

The calculation in this study compares the t-value calculated by t-Table, where the alternative hypothesis will be accepted if the calculated $t$ value is greater than $t$ Table at $\alpha=5 \%$. The critical value that must be met is t-table of 1.96. That is, if the value of t-table is greater than 1.96, then there is a significant positive between the exogenous latent construct and the endogenous latent construct tested.

The following are hypotheses testing in this study:

$\mathrm{H}_{1} \quad$ : Islamic Physical Attributes has significant influence on Tourist Preference of ShariaCompliance Hotel

$\mathrm{H}_{2}$ : Islamic Physical Attributes mediated by Religiousity has significant influence on Tourist Preference of Sharia-Compliance Hotel

$\mathrm{H}_{3}$ : Islamic Non-Physical Attributes has significant influence on Tourist Preference of ShariaCompliance Hotel

$\mathrm{H}_{4}$ : Islamic Non-Physical Attributes mediated by Religiousity has significant influence on Tourist Preference of Sharia-Compliance Hotel

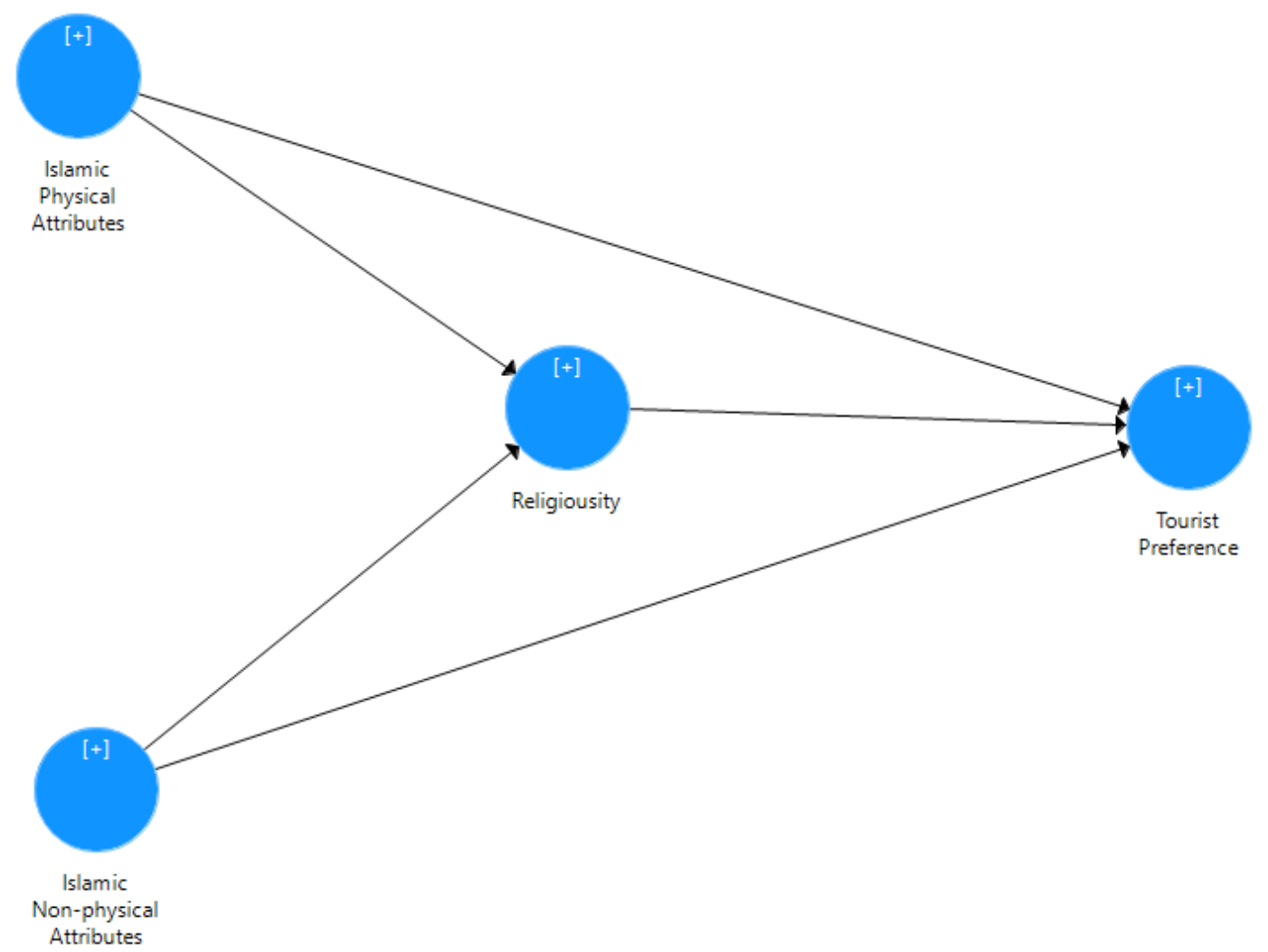

Figure 1: Theoretical Framework 


\section{RESULT AND DISCUSSION}

The first analysis is filtering questions regarding the respondent of muslim and have ever been staying in hotel. All of 100 respondents are met the criteria. Thus, continue to next analysis. The demographic profile for this study shows in Table 1 below. Based on the table it was found that majority of respondent in this study are males with $55 \%$ and female $45 \%$. In terms of age of respondents, majority of respondents are in the age of 16 to 25 years old with $51 \%$ followed by above 45 years old of $21 \%$ and $20 \%$ respondents are in the age of 26 to 35 years old. Based on occupation, students hold a dominant of respondents with $33 \%$, followed by private employees of $27 \%$ and government employees of $25 \%$. Domicile of respondents are dominantly living in Central Java of $46 \%$ and Jabodetabek (Jakarta, Bogor, Depok, Tanggerang, and Bekasi) of 42\%. After analyzing the demographic profile of respondents, continue with the third section of statistical analysis to answer the hypothesis of this study. The statistical tools used in this study is Smart-PLS SmartPLS 3.2.8. software to analyse the measurement model and structural model. The goodness of fit of the measurement model must be considered, thus result of convergent validity, discriminant validity, and reliability must be meet the criteria. The result is show in Table 2.

Table 1: Demographic of respondents

\begin{tabular}{llll}
\hline Variable & Categories & Frequency & Percentage \\
\hline Gender & Male & 55 & 55 \\
& Female & 45 & 45 \\
& 16-25 years old & 51 & 51 \\
& 26-35 years old & 20 & 20 \\
Occupation & 36-45 years old & 8 & 8 \\
& Above 45 years old & 21 & 21 \\
& Student & 33 & 33 \\
& Government employees & 25 & 25 \\
& Private employees & 27 & 27 \\
& Entrepreneur & 5 & 5 \\
& Professional & 10 & 10 \\
& Central Java & 46 & 46 \\
& DI Yogyakarta & 6 & 6 \\
& East Java & 4 & 4 \\
& Jabodetabek & 42 & 42 \\
& Kalimantan & 2 & 2 \\
\hline
\end{tabular}

\section{Measurement Model Result}

In the measurement model, to see the goodness of fit using convergent validity, discriminant validity, and reliability. To asses convergent validity used factor loadings, composite reliability (CR), and Average Variance Extracted (AVE) shows in Table 2. Based on Table 2, the result of convergent validity show that all items have a factor loading greater than 0.5 . For the CR the minimum value should be 0.70 and the value of AVE in each latent variable is greater than 0.5 . For the Islamic Physical Attributes consists of 7 items, item IPA6 need to be removed because the factor loading is less than 0.60. Variable Islamic Non-Physical Attributes which consist of 5 items, one items (INPA2) need to be removed. For religiousity, which consist of total 15 items, four items need to be removed as the factor loadings were less than 0.60 . for CR all constructs (latent variables) are meet the criteria of higher than 0.70 also AVE were all higher than 0.50 . For discriminant validity use value of cross-loading and Fornell-Larcker criterion., result shows in Table 3. The square root of the AVE of the latent variable is higher than the correlations of 
other constructs mention in Table 3. Based on results mentioned, indicated sufficient convergent and discriminant validity as the loading of each indicator is greater than all of its cross-loadings.

Table 2: Result of Convergent Validity

\begin{tabular}{|c|c|c|c|c|}
\hline Construct & Items & Loadings & CR & AVE \\
\hline \multirow[t]{6}{*}{ Islamic Physical Attributes } & IPA1 & 0.823 & 0.911 & 0.631 \\
\hline & IPA2 & 0.887 & & \\
\hline & IPA3 & 0.801 & & \\
\hline & IPA4 & 0.782 & & \\
\hline & IPA5 & 0.761 & & \\
\hline & IPA7 & 0.699 & & \\
\hline \multirow[t]{4}{*}{ Islamic Non-Physical Attributes } & INPA1 & 0.839 & 0.856 & 0.599 \\
\hline & INPA3 & 0.807 & & \\
\hline & INPA4 & 0.734 & & \\
\hline & INPA5 & 0.708 & & \\
\hline \multirow[t]{11}{*}{ Religiousity } & $\mathrm{R} 2$ & 0.629 & 0.918 & 0.507 \\
\hline & R3 & 0.668 & & \\
\hline & $\mathrm{R} 7$ & 0.654 & & \\
\hline & $\mathrm{R} 8$ & 0.676 & & \\
\hline & R9 & 0.722 & & \\
\hline & $\mathrm{R} 10$ & 0.677 & & \\
\hline & $\mathrm{R} 11$ & 0.757 & & \\
\hline & $\mathrm{R} 12$ & 0.830 & & \\
\hline & $\mathrm{R} 13$ & 0.618 & & \\
\hline & $\mathrm{R} 14$ & 0.780 & & \\
\hline & $\mathrm{R} 15$ & 0.787 & & \\
\hline \multirow[t]{3}{*}{ Tourist Preference } & TP1 & 0.835 & 0.880 & 0.710 \\
\hline & TP2 & 0.901 & & \\
\hline & TP3 & 0.789 & & \\
\hline
\end{tabular}

Table 3: Disciminant validity result

\begin{tabular}{llllll}
\hline Constructs & & & & \\
\hline Islamic Non-physical Attributes & 0.774 & & & \\
Islamic Physical Attributes & 0.605 & 0.794 & & \\
Religioustity & 0.544 & 0.386 & 0.712 & \\
Tourist Preference & 0.633 & 0.361 & 0.553 & 0.843 \\
\hline
\end{tabular}

\section{Structural Model Result}

Figure 2 shows that the R-square value for dependent variable (endogenous latent variable). The $\mathrm{R}$-square value for the endogenous variables Tourist preference is 0.465 , meaning the percentage of Tourist Preference which can be explained by Islamic Physical Attributes and Islamic NonPhysical Attributes is $46.5 \%$. 


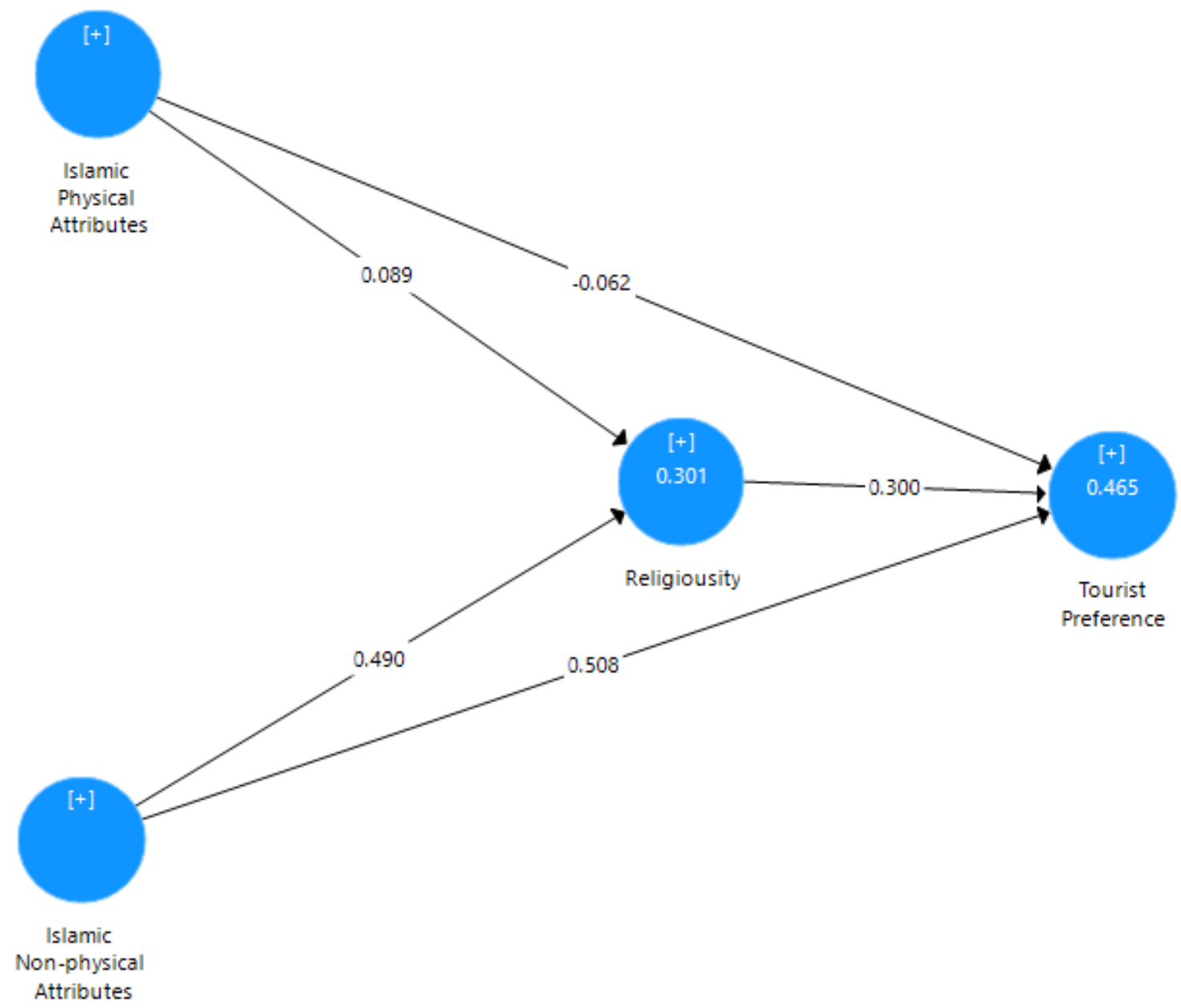

Figure 2: R-square result

\section{Hypothesis Testing}

The t-value test is intended to test the influence of independent variables (exogenous latent variables) and dependent variables (endogenous latent variables). T-value in each exogenous latent variable to endogenous latent variables is obtained from the bootstrapping process using SmartPLS 3.2.8. The result of t-value is summarized in Table 4. Based on the table, the result of $t$ value to be accepted should be higher than the t-table of 1.96 with significant level of 0.05 . It is shows that the $t$ value of Islamic Physical Attributes influence Tourist Preference is lower than $t$ table $(\mathrm{t}$ value $=0.617, \mathrm{p}$ value $=0.538)$ also Islamic Physical Attributes mediated by Religiousity influence Tourist Preference is lower than t table ( $\mathrm{t}$ value $=0.599, \mathrm{p}$ value $=0.549$ ). It can be concluded that there is not signifant influence of Islamic Physical Attributes on Tourist Preference. The t value result of Islamic Non-Physical Attributes influence Tourist Preference is higher than $\mathrm{t}$ table $(\mathrm{t}$ value $=4.216, \mathrm{p}$ value $=0.000$ ) also Islamic Non-Physical Attributes mediated by Religiousity influence Tourist Preference is higher than $t$ table $(\mathrm{t}$ value $=2.366, \mathrm{p}$ value $=0.018$ ). Based on result, the summrise of hypothesis result shows in Table 5

Tabel 4: The Structural model result

\begin{tabular}{lllll}
\hline \multicolumn{1}{c}{ Path } & T-value & P-value & Conclusion \\
\hline Islamic Physical Attributes $\longrightarrow$ Tourist Preference & 0.617 & 0.538 & Not Significant \\
Islamic Physical Attributes $\longrightarrow$ Religiousity $\longrightarrow$ & 0.599 & 0.549 & Not Significant
\end{tabular}

Tourist Preference 


\begin{tabular}{llll} 
Islamic Non-Physical Attributes $\longrightarrow$ Tourist & 4.216 & 0.000 & Significant \\
$\begin{array}{l}\text { Preference } \\
\begin{array}{l}\text { Islamic Non-Physical Attributes } \longrightarrow \text { Religiousity } \longrightarrow \\
\text { Tourist Preference }\end{array}\end{array}$ & 2.366 & 0.018 & Significant \\
\hline
\end{tabular}

Table 5: Hypothesis Result

\begin{tabular}{|c|c|c|}
\hline Hypothesis & Result & Conclusion \\
\hline $\begin{array}{l}\mathrm{H}_{1} \text { : Islamic Physical Attributes has significant influence on Tourist } \\
\text { Preference of Sharia-Compliance Hotel }\end{array}$ & Unsupported & Rejected \\
\hline $\begin{array}{l}\mathrm{H}_{2} \text { : Islamic Physical Attributes mediated by Religiousity has } \\
\text { significant influence on Tourist Preference of Sharia-Compliance } \\
\text { Hotel }\end{array}$ & Unsupported & Rejected \\
\hline $\begin{array}{l}\mathrm{H}_{3} \text { : Islamic Non-Physical Attributes has significant influence on } \\
\text { Tourist Preference of Sharia-Compliance Hotel }\end{array}$ & Supported & Accepted \\
\hline $\begin{array}{l}\mathrm{H}_{4} \text { : Islamic Non-Physical Attributes mediated by Religiousity has } \\
\text { significant influence on Tourist Preference of Sharia-Compliance } \\
\text { Hotel }\end{array}$ & Supported & Accepted \\
\hline
\end{tabular}

\section{Discussion}

The statistical result provided support to answer hypothesis relationship. The study found that only Islamic Non-Physical Attributes are significantly influence on Tourist Preference also mediated by Religiousity. Whereas, Islamic Physical Attributes were not significantly influence on Tourist Preference mediated by Religiousity. The result is contradicted with result from Battour \& Ismail (2011) whereas the islamic physical attribute having the major tourist preference. The result of this study of Islamic Physical Attributes not significantly influence on tourist preference because most of hotels in Indonesia (regardless the Sharia-compliance or general hotel) are already fulfill the criterias. Criterias such as forbidden on providing port or other haram foods, selling liquor, providing worship tools, worship facilities, and also providing toilets in accordance with Islamic rules.

On the other hand, Islamic Non-Physical Atributes is significantly influence on tourist preference on Sharia Compliance Hotel. As mentioned in literature, Non-physical attributes such as appropriate entertainment, separate floow for men and women, separated swimming pool also gymnastic for both men and women. Looking into current hotel facilities, most of hotel were not implement yet regarding the Islamic Non-Physical Attributes. Thus, Islamic Non-Physical Attributes is necessary to be implemented. Supported by Battour \& Ismail (2011) that the implementation of Islamic Non-physical Attributes still limited in specific countries only.

The role of religiousity in mediating the Islamic Attributes on Tourist Preference seem to be lowering the importance. Looking into each Islamic Attributes (Physical Attributes and NonPhysical Attributes), when analyse using mediating of Religiousity, the value of $t$ is decreasing. Therefore, tourist preference, the elements of religiousity in this study is not strengthen the result as a mediator. The result shows fdifferent views with Huber \& Huber (2012) mentioned that religiousity able to affect the personality.

\section{CONCLUSION AND RECOMMENDATION}

Based on the result, Islamic Physical Attributes has not significantly influence tourist preference on staying in Sharia-compliance hotel, whereas Islamic Non-physical Attributes has. Additionally, Religiousity found not significantly mediated the Islamic Physical Attributes, 
hence, significantly mediated the Islamic Non-physical Attributes. However, the result found that mediated by Religiousity, the value is decreasing. This study offers several practical implications for the hotel industry. To win in the competition of Sharia-compliance Hotel, the most suitable stategy is emphasing the Islamic Non-Physical Attributes. Added, looking into the limited number of Sharia-compliance hotel available in Indonesia, by providing the Islamic Nonphysical Attributes hope to get the competitive advantage in the hotel industry. Futher, marketing aspects should also be emphasis to inform in order to attract tourist prefer to stay in Shariahcompliance Hotel.

The limitation of this study comes from several aspects: the scope of study, the number of respondents, and the variable considered. First, the scope of this study is quite bias. After collecting the data, it was found that majority of respondent are domicile in Central Java and Jabodetabek, and other places are few numbers. In the next study, it recommended to spread the data equally, thus it is hope to get better result. Second, the number of respondents should be more than 100 to get higher result as more sample will have better result. Last, for future study might used varieties of variables which relates to Tourist Preference on staying in Shariahcompliant Hotel.

\section{Acknowledgement}

Researchers would like to thank the Department of Research and Community Development of President University for the support given in the form of research funding assistance that supports this research well.

\section{REFERENCE}

Al-Quran dan terjemahannya (2008) Departemen Agama RI. Bandung: Diponegoro

Battour, M. M., Battor, M. M., \& Ismail, M. (2012). The mediating role of tourist satisfaction: A study of Muslim tourists in Malaysia. Journal of Travel \& Tourism Marketing, 29(3), 279297.

Battour, M., Ismail, M. N., Battor, M., \& Awais, M. (2014). Islamic tourism: an empirical examination of travel motivation and satisfaction in Malaysia. Current Issues in Tourism, 20(1), 50-67. https://doi.org/10.1080/13683500.2014.965665

Battour, M., Ismail, M. N., \& Battor, M. (2011). The impact of destination attributes on Muslim tourist's choice. International Journal of tourism research, 13(6), 527-540.

Battour, M., Ismail, M. N., \& Battor, M. (2011). The impact of destination attributes on Muslim tourist's choice. International Journal of tourism research, 13(6), 527-540.

Chanin, O., Sriprasert, P., Rahman, H. A., \& Don, M. S. (2015). Guidelines on halal tourism management in the andaman sea coast of thailand. Journal of Economics: Business and Management, 3(8), 791-794.

Committee for Economic and Commercial Cooperation of the Organization of Islamic Cooperation. (2016). Muslim Friendly Tourism: Understanding the Demand and Supply Sides In the OIC Member Countries. Muslim Friendly Tourism, (February), 1-110.

Creswell, J. W. (2014). Research Design: Qualitative, Quantitative, and Mixed Methods Approaches - John W. Creswell - Google Books. Retrieved May 16, 2017, from https://books.google.com.my/books?id=EbogAQAAQBAJ\&printsec=frontcover\&dq=editi ons:FbEcIQBaiW0C\&hl=en\&sa=X\&ved=0ahUKEwjXo6a2v_PTAhVMpo8KHcBEByYQ 6AEIIjAA\# $=$ onepage $\& \mathrm{q} \& \mathrm{f}=$ false

Eid, R., \& El-Gohary, H. (2015). The role of Islamic religiosity on the relationship between perceived value and tourist satisfaction. Tourism Management, 46, 477-488. 
El-Adly, M. I., \& Eid, R. (2017). Dimensions of the perceived value of malls: Muslim shoppers' perspective. International Journal of Retail \& Distribution Management, 45(1), 40-56. https://doi.org/10.1108/IJRDM-12-2015-0188

Enda, L. A. (2015). Laporan Akhir Kajian Pengembangan Wisata Syariah

Garson, G. D. (2016). Partial Least Squares: Regression \& Structural Equation Models. G. David Garson and Statistical Associates Publishing.

Henderson, J. C. (2010). Sharia-compliant hotels. Tourism and Hospitality Research, 10(3), 246254.

Huber, S., \& Huber, O. W. (2012). The centrality of religiosity scale (CRS). Religions, 3(3), 710724.

Idris, J., \& Abdul Wahab, N. (2015). The competitive advantages of Sharia-compliant hotel concept in Malaysia: SWOT analysis. Fakulti Pengurusan \& Muamalah.

Islam, T., \& Chandrasekaran, U. (2015). Religiosity and ecologically conscious consumption behaviour. Asian Journal of Business Research ISSN, 1178, 8933.

Mohsin, A., Ramli, N., \& Alkhulayfi, B. A. (2015). Halal Tourism: Emerging Opportunities. Tourism Management Perspectives. http://doi.org/10.1016/j.tmp.2015.12.010

Muslim Travel. (2018). Retrieved from Global Muslim Travel Index : https://www.crescentrating.com/reports/mastercard-crescentrating-global-muslim-travelindex-gmti-2018.html

Putra, E. H., Hati, S. R. H., \& Daryantic, S. (2016). Understanding Muslim Customer Satisfaction with Halal Destinations: The Effects of Traditional and Islamic Values. International Conference on Business and Economics, 167-175. https://doi.org/10.15405/epsbs.2016.11.02.16

Sahida, W., Rahman, S. A., Awang, K., \& Man, Y. C. (2011, October). The implementation of shariah compliance concept hotel: De Palma Hotel Ampang, Malaysia. In 2nd International Conference on Humanities, Historical and Social Sciences (Vol. 17, pp. 138142).

Sarwono, J. (2011). Mengenal path analysis: sejarah, pengertian dan aplikasi. Ilmiah Manajemen Bisnis.

Sugiyono. (2017). Metode Penelitian Kuantitatif, Kualitatif, dan R\&D. Bandung: Alfabeta.

Sugiyono, P. D. (2013). Metode Penelitian Manajemen. Bandung: Alfabeta, CV.

Wingett, F., \& Turnbull, S. (2016b). Halal holidays: exploring expectations of Muslim-friendly holidays. Journal of Islamic Marketing, 8(4), 642-655. https://doi.org/10.1108/JIMA-01$\underline{2016-0002}$

WTTC. (2017). Tourism Economic Impact 2017: World. World Travel \& Tourism Council.

Sofyan, R. (2015). Wonderful Indonesia Muslim Friendly Destination.

Zamani-Farahani, H., \& Musa, G. (2012). The relationship between Islamic religiosity and residents' perceptions of socio-cultural impacts of tourism in Iran: Case studies of Sare'in and Masooleh. Tourism Management, 33(4), 802-814. 